\title{
Characterization of silage production and the use by dairy farmers in the West of Santa Catarina state
}

\section{Caracterização da produção e do uso de silagem por produtores de leite no Oeste de Santa Catarina}

\author{
Adenor Vicente Wendling ${ }^{1 *}$; Luiz Carlos Pinheiro Machado Filho
}

\begin{abstract}
Silage has been widely used in dairy production. However, little is known about its use at production level. The goal of this study was to characterize production and usage of silage for the dairy farming in Western Santa Catarina state. Thirty farms were selected randomly by their geographical location, in 11 municipalities of the West of Santa Catarina state, and they were invited to participate in the research. Out of these 30 farms, 6 did not have any dairy activity, and 2 preferred not to participate in the research, thus were not included. Semi-structured interviews and on-site visits were then performed. All data were analyzed with the software $\mathrm{R}$ version 3.2.2. 95\% of the farmers produced and fed silage to animals. Out of the 22 farmers participating in the study, $82 \%$ provided silage for dairy cows during the whole year; in $86 \%$ of these farms, the silage was fed right after milking, in an average amount of 6.06 $\pm 0.63 \mathrm{~kg}$ DM (dry matter) $\mathrm{AU}^{-1}$ (animal unit, $500 \mathrm{~kg}$ ) day ${ }^{-1}$. The average area used for maize production was 8.46 ha, representing $59 \%$ of the area destined to dairy farming. The average silage production was 8.8 and $7.6 \mathrm{t} \mathrm{ha}^{-1}$ year $^{-1}$ in the season and off-season crop respectively, without significant differences. In most silage production areas, the no-tillage system is adopted, with the use of pesticides, chemical fertilization and transgenic seeds, without soil covering or crop rotation. Farms that fertilized maize based on soil analysis had the greatest silage yield, compared to the ones that fertilized without relying on soil analysis. The use of different types of pesticides and fertilizer quantities was not correlated to the silage production volume. Overall the production systems and the quantity of silage produced and fed to the cows do not follow technical criteria; thus silage yield and use could be improved if following strategies to better allocate crop inputs.
\end{abstract}

Key words: Maize cultivation. Milk. Pesticide. Silage density.

\section{Resumo}

A silagem tem sido amplamente utilizada na produção leiteira. Entretanto, há pouca informação sobre como é utilizada e produzida. O objetivo desse estudo foi caracterizar os sistemas de produção e uso de silagem para a atividade leiteira no Oeste Catarinense. Foram selecionados 30 estabelecimentos às cegas em mapa digital, em 11 municípios do Extremo Oeste Catarinense, e convidados para participar da pesquisa. Desses 30 estabelecimentos, 6 não possuíam atividade leiteira e 2 preferiram não participar da pesquisa. Foram então realizadas entrevistas semi estruturadas e visitas in loco em 22 estabelecimentos. Os dados foram analisados com o software R versão 3.2.2. 95\% dos estabelecimentos produzem e fornecem silagem aos animais. Em $82 \%$ das propriedades a silagem é fornecida às vacas

\footnotetext{
1 Dr. em Agroecossistemas, Laboratório de Etologia Aplicada, LETA, Departamento de Zootecnia e Desenvolvimento Rural, Universidade Federal de Santa Catarina, UFSC, Florianópolis, SC, Brasil. E-mail: adenor.wendling@gmail.com

2 Eng $^{\circ}$ Agr $^{\circ}$, Prof. Dr., Laboratório de Etologia Aplicada, LETA, Departamento de Zootecnia e Desenvolvimento Rural, UFSC, Florianópolis, SC, Brasil. E-mail: pinheiro.machado@ufsc.br

* Author for correspondence
} 
leiteiras durante todo o ano, e em $86 \%$ destes o fornecimento é realizado logo após as ordenhas, numa quantidade média de $6.06 \pm 0.63$ (Erro Padrão) $\mathrm{kg}$ de MS (matéria seca) $\mathrm{UGM}^{-1}$ (500 kg) dia ${ }^{-1}$. A área média utilizada para a produção de silagem é de $8,46 \mathrm{ha}^{-1}$, representando $59 \%$ da área destinada para a atividade leiteira. A produção média de silagem é de 8,8 e 7,6 $\mathrm{t} \mathrm{ha}^{-1}$ ano $^{-1}$ na safra e safrinha respectivamente, sem diferença significativa. Na maioria das áreas de produção de silagem adota-se o plantio direto, com uso de agrotóxicos, adubação química e sementes transgênicas, sem cobertura do solo ou rotação de culturas. Nos 5 estabelecimentos que adubaram o milho com base na análise de solo foi alcançado maior produção de silagem, se comparada aos que adubaram sem basear-se na análise do solo. O uso de diferentes tipos de agrotóxicos e quantidade de adubação não apresentaram correlação com o volume de produção de silagem. Em geral, a produção e a quantidade de silagem fornecida aos animais não seguem critérios técnicos, de modo que o rendimento e o uso poderiam ser melhorados através de melhor alocação dos insumos na lavoura.

Palavras-chave: Agrotóxico. Cultivo de milho. Densidade de silagem. Leite.

\section{Introduction}

Apart from pasture, maize silage is, perhaps, the main feed supplied to dairy cows in the South of Brazil. In the Western Santa Catarina state, one of the most important and growing dairy region in Brazil (IBGE, 2015), this is not different (BALCÃO et al., 2017; COSTA et al., 2013; HONORATO et al., 2014; KUHNEN et al., 2015). In this region dairy production is characterized by a great diversity of systems with different herd size, breed and feeding strategies; which may be categorized into four production systems: the extensive system, the conventional pasture-based system, the semiintensive system (BALCÃO et al., 2017) and the organic system (COSTA et al., 2013; HONORATO et al., 2014; KUHNEN et al., 2015). In the "organic system" category, most farms use the Voisin's Rational Grazing (MACHADO FILHO et al., 2014; WENDLING; RIBAS, 2013); a type of intensive pasture management.

Technically, the goal to feed silage to cattle is to compensate the pasture deficit in quantity and/ or quality, due to the seasonal differences in pasture yield and nutritional value (GOMES et al., 2004; MITTELMANN et al., 2005), or during periods of heat stress (KAISER et al., 2004). Currently, however, it is apparent that farmers are using silage as a strategy to increase milk production and, in many cases, regardless of pasture quality and time of the year (KUHNEN et al., 2015). Increasing use of maize silage has been correlated with higher milk production (PÉREZ-PRIETO et al., 2011), but also with rising environmental impacts (BACENETTI; FUSI, 2015; BASSET-MENS et al., 2009), which is of concern of researchers and field technicians. In pasture based systems, excessive use of silage may promote the substitution of pasture by silage (PENNO et al., 2006), increasing production costs further.

Maize silage use for dairy production is of great importance in other regions of the country In Santa Catarina, silage production has been increasing in recent years, representing approximately 213 thousand ha in the 2015/2016 harvest (SANTA CATARINA, 2017).

One of the reasons maize silage is so widely used, is its high productivity, even though with great variation depending on climate, season, fertility of the soil, genetics and fertilization. The interest in maize silage for dairy cattle usage has been growing lately, due to some advantages in relation to other crops. Not only maize crop deliver a higher amount of mass per hectare than other crops, such as barley, but also has a higher energy concentration (GUYADER et al., 2017). Moreover, the use of maize silage to feed cattle, in comparison with barley or ryegrass silage, result in a reduction of $8-14 \%$ of $\mathrm{CH}_{4}$ enteric from the cows (BENCHAAR CH4 et al., 2014; VAN MIDDELAAR et al., 2013). 
The growing use of maize, its nutritive value and positive environmental effects compared to other crops, show the importance of its silage use for dairy cattle. However, it lacks information on the specificity of its production and use by farmers. The apparent use of silage as a strategy to increase milk production and, in many cases, regardless of pasture quality and time of the year, deserves further investigation. Therefore, the objective of this study was to characterize and understand how silage is produced and the strategies of its use by dairy farmers in Western Santa Catarina state.

\section{Material and Methods}

The study was approved by the human research ethics committee of the UFSC (CAAE: 51878115.3.0000.0121), and conducted in 11 municipalities of Western Santa Catarina state ${ }^{3}$, in
April 2015 and January 2016. Thirty farms were selected randomly within these municipalities, according to the following steps: the area of interest was divided by the number of proprieties participating in the study $(1807.33 / 30=60$ $\left.\mathrm{km}^{-2}\right)$. After that, the square root of the quotient $(\sqrt{60}=7.7 \mathrm{~km})$ was calculated in order to define the distance between the farms to be chosen. This distance was transformed in a proportional scale for the "here maps". For every corresponding distance, a dot was marked on the map and then adjusted to the head office of the closest farm and inserted in the GPS toll "here maps ${ }^{\circledR \text { " }}$ and then visited. The study was conducted in 22 out of the 30 farms (Figure 1), since in six of them there was no dairy production, and two did not want to participate. All the farms in this study are located in Western Santa Catarina, in a Cfa and Cfb climate (ALVARES et al., 2013).

Figure 1. Map of the Western region of Santa Catarina and location of the farms participating in the study.

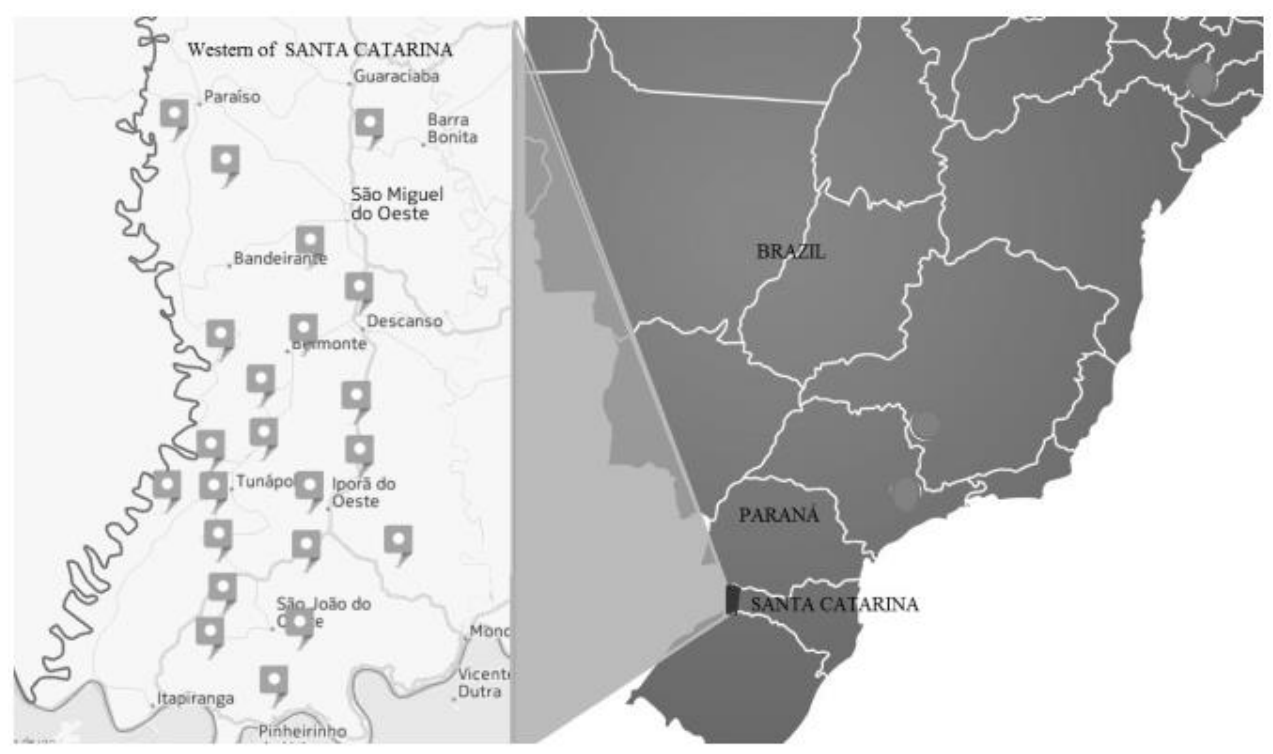

3 Itapiranga, São João do Oeste, Tunápolis, Iporã do Oeste, Descanso, São Miguel do Oeste, Barra Bonita, Santa Helena, Bandeirante, Paraíso and Belmonte. The total area of these cities is $1807.3 \mathrm{~km}^{-2}$, based on data from http://www.sc.gov.br/ municipios, accessed on 12/05/2015.

4 Information about HERE Maps may be accessed at: https://help.here.com/wp8/maps/. 
Data were collected in two visits performed in each farm, April 2015 and January 2016. During each visit, an interview and an on-site check of the silos and the silage crop areas were performed. Interviews were based on semi-structured questionnaires, collecting the information on: general data of the property (area, number of cows, milk production, pasture area and management, animal feeding regime and feedstuff); silage production (area used, production system, seed type, quantity and type of fertilizer used, quantity and type of pesticide used, yield, silo type and covering, reasons for the use of silage); silage feeding regime (quantity per animal, time of the day, time of the year, place): concentrate feeding regime (quantity per animal, time of the day, time of the year, place).

During the first visit, the areas for silage production were measured, and so were the characteristics and sizes of the silos. During the second visit, silage samples were collected in order to analyze their density and dry matter percentage. The silage quantity given to animals was reassessed.

The estimated amount of nutrients applied in the culture of maize was obtained multiplying the quantity of used chemical and/or organic fertilizer by its concentration. In order to quantify the main nutrients in animal manure the following quantities were considered: for liquid swine manure $2.88 \mathrm{Kg}$ Nitrogen (N) m-3 (SCHERER et al., 1996), $2.4 \mathrm{~kg}$ phosphorus $(\mathrm{P}) \mathrm{m}^{-3}$; broiler litter, 3\% $\mathrm{N}$ and 3\% $\mathrm{P}$ (CQFS-RS/SC, 2004).

In order to estimate the silage yield, all silos filled during the 2014/2015 season were measured. The volume of each silo was calculated through the software SketchUp Pro $2014^{\circledR 5}$. Only open silos were sampled to estimate silage density (SD) and DM, what happened in 16 farms that had their silage assessed for DM and SD. Estimate of the silage mass of empty or closed silos was made using DM and SD from silos of the same farm. In the five farms where the silos were empty, the average SD and $\mathrm{DM}$ of the 16 sampled silos were considered $\left(\mathrm{SD}=549.7 \mathrm{~kg} \mathrm{~m}^{-3}\right.$, and $\left.\mathrm{DM}=33 \%\right)$. One farm do not produce silage.

Sample collection and estimation of SD was carried out at three heights of the silage face. For the upper part (0 to $30 \mathrm{~cm}$ ) a sample was collected at $15 \mathrm{~cm}$ from the silo upper edge. For the bottom, a sample was collected at $25 \mathrm{~cm}$ from the bottom of the silo, and for the middle part of the silo a sample was collected in the middle of the silage face. The samples were collected using a PVC ring $10 \mathrm{~cm}$ in diameter and $15 \mathrm{~cm}$ long, introduced under pressure to remove a known volume of silage. The material was weighed with a precision scale and the SD of each sample was calculated by dividing the weight by the sample volume. These three samples were then mixed and a sub-sample of approximately 300 grams was sent to the laboratory to oven drying at $60{ }^{\circ} \mathrm{C}$ for $72 \mathrm{~h}$ to calculate DM.

The statistical analyses were performed using the $\mathrm{R}$ software, version 3.3.2 (R CORE TEAM, 2016). Silage yield, density, amount of silage, as well as concentrate, and milk yield were normally distributed; assessed via Shapiro-Wilk test (SHAPIRO; WILK, 1965). The comparison of silage production averages in relation to the pesticide type and to the use of soil analysis was obtained by Tukey's test $(\mathrm{p}<0.05)$. The comparison of silage production averages in the season and off-season crop was obtained by $t$ test $(p<0.05)$. A regression analysis of the amount of silage and concentrate supplied ( $\mathrm{kg}$ of DM/cow/day) as an independent variable on the milk production $(\mathrm{t} / \mathrm{ha} /$ year and $t / c o w / y e a r)$ as the dependent variable, was performed using geom_smooth with $1 \mathrm{~m}$ method by ggplot2 packpage (WICKHAM, 2016).

5 The following steps were followed to calculate the area of bag silos: a) a straight line was drawn with the same length as the silo's width; b) starting from the initial and final points of the line, a curve was drawn with the " 2 Point Arc" tool, with the same height as the silo's; c) the area of the circular segment was visualized with the "identity information" tool and later multiplied by the silo's length. For the bunker silo, the drawing of the "bunker" was added to the segment. 


\section{Results and Discussion}

The farms that participated in this study had an average area of $24.76(\mathrm{Q} 1=15.0 ; \mathrm{Q} 3=28.75)$ ha of their own land and $24.2(\mathrm{Q} 1=17.25 ; \mathrm{Q} 3=29.75)$ cows. The average productivity of these cows in 2014 was 4360 (Q1=3600; Q3=4680) $\mathrm{L} \mathrm{cow}^{-1}$ year $^{-1}$, whereas the milk productivity per area occupied by the activity was 8830 (Q1=5790; Q3=11490) L $\mathrm{ha}^{-1}$ year $^{-1}$. These data are similar to the ones found by Kuhnen et al. (2015) and SANTA CATARINA (2017), indicating that the studied farms are representative of the region. In relation to the types of silos, 33 bunker-type silos were found (29 with no covering and four with masonry covering) and 28 stack-type silos.

In only three, out of the 22 assessed farms, silage supplementation is restricted to periods of pasture scarceness (Table 1), as a resource to reduce the effects of the seasonal pasture deficit. On the other hand, concentrate is supplied year round in 21 of the farms. Other recent studies have shown a tendency for conventional intensive production to use silage and concentrate year round and organic and / or pasture based production mostly during the periods of pasture scarceness (BALCÃO et al., 2017; KUHNEN et al., 2015). In the Western Center region of Paraná, $100 \%$ of the researched dairy establishments provide maize silage throughout the year for animals (SILVA et al., 2015). In contrast, in Minas Gerais $77 \%$ of the dairy farmers provide silage only during the dry season, while the other $23 \%$ supply it during the whole year (BERNARDES et al., 2013). Regardless of the management system almost all dairy farms rely on maize silage for at least part of the year. As we found in this study, in most farms there is a generalized use of silage year round, showing the relevance of its use for the dairy industry.

Table 1. Number of farms, out of 22 studied in Western Santa Catarina state, supplying concentrate (C) and silage (S).

\begin{tabular}{lcc}
\hline \multicolumn{1}{c}{ Time of the year } & $\mathrm{C}$ & $\mathrm{S}$ \\
\hline To balance the seasonal fluctuation & - & 3 \\
During the whole year (more in winter) & - & 3 \\
During the whole year (even quantity) & 21 & 15 \\
No supply & 1 & 1 \\
TOTAL & 22 & 22 \\
\multicolumn{1}{c}{ Time of the day } & 20 & 19 \\
\hline After both milking & - & 1 \\
After night milking & 1 & 1 \\
For 24 h a day (ad libitum) & 21 & 21 \\
TOTAL & & \\
\hline
\end{tabular}

In 21 farms silage was provided right after the morning and afternoon milking; only in one farm silage was fed once a day. Concentrate is also given after milking, together with the silage, in most farms (Table 1). Giving silage and feeding right after milking is coincident with the time when cows present higher grazing events (TAWEEL et al., 2004), and may affect pasture intake, once the size of the bit and grazing time are inversely proportional to the filling of the rumen (GREGORINI et al., 2008). Therefore, cows may reduce pasture ingestion depending on the amount and timing of the supplement received. High quality pasture may reduce the substitution rate (PENNO et al., 2006), whereas offering silage $1 \mathrm{~h}$ before grazing increase substitution rate compared to $9 \mathrm{~h}$ (AL-MARASHDEH et al., 2016). 
The amount of silage and concentrate supplied per lactating cow (AU, animal unit) and per day averaged $6.06 \pm 0.63$ and $3.09 \pm 0.41 \mathrm{~kg}$ of DM, respectively, in the 21 farms. There is a high variation in the amount of silage fed per day in the assessed farms. In 11 farms, silage fed was lower than $5 \mathrm{~kg} \mathrm{AU}^{-1}$ day $^{-1}$, whereas in 2 farms the amount was higher than $10 \mathrm{~kg} \mathrm{AU}^{-1}$ day $^{-1}$. In this study the amount of silage and concentrate fed per day was higher compared to that found by Kuhnen et al. (2015) on their organic and low-input farms, while their high input farms provided cows with greater amount of silage and concentrate. This difference can be explained by sampling methods, since Kuhnen et al. (2015) sampled eight establishments for each production system, while in our study we haven't made differentiated for production systems.

The use of both (silage plus concentrate) had a positive effect on milk production per cow $\left(\mathrm{y}=2.57+0.20 \mathrm{x} ; \mathrm{p}<0.001 ; \mathrm{R}^{2}=0.46\right)$, and per area $\left(\mathrm{y}=5.04+0.435 \mathrm{x} ; \mathrm{p}<0.01, \mathrm{R}^{2}=0.27\right) \quad$ (Figure 2). However, these results must be evaluated carefully, once a positive regression was found between the amount of silage and concentrate fed to the cows $\left(y=1.73 x ; \quad p<0.001 ; \quad R^{2}=0.88\right)$. The performed correlations do not "separate" supplying one or the other. As an observational study, it wasn't possible to avoid silage and concentrate having a confounding response in milk production, since both maize silage and concentrate have higher energy content than pastures (NRC, 2001). There is great variation on the response of amount of silage fed per cow, which seems to be related to pasture quality. Feeding $8 \mathrm{~kg}$ DM of a mixture $7: 1$ of maize silage and soybean meal for lactating cows either on a low or high quality pasture, had different effects on pasture consumption and milk production. When grazing low quality pasture, cows reduced its consumption to a rate of 0.51 (decrease of pasture DM ingestion per $\mathrm{kg}$ of silage DM), and increased milk production by $5.3 \mathrm{~kg}$ day $^{-1}$. On the other hand, when grazing high quality pasture and the same supplementation, cows reduced the consumption of pasture to a rate of 0.75 and milk increase by only $1.4 \mathrm{~kg}$ day $^{-1}$ (PÉREZ-PRIETO et al., 2011). Likewise, cows grazing a fresh paddock everyday under rotational grazing increased milk production by only 1.4 to $1.6 \mathrm{~kg} \mathrm{cow}^{-1} \mathrm{day}^{-1}$ in response to 5.6 to $6.6 \mathrm{~kg}$ of silage (DM) daily supplement (FERRIS et al., 2008).

Figure 2. Regression of the amount of silage and concentrate supplied $\left(\mathrm{kg}\right.$ of $\left.\mathrm{DM} \mathrm{cow} \mathrm{c}^{-1} \mathrm{day}^{-1}\right)$ on the milk production per area $\left(\mathrm{t} \mathrm{ha}^{-1}\right.$ year $\left.^{-1}\right)$ and per cow $\left(\mathrm{t} \mathrm{cow}^{-1}\right.$ year $\left.^{-1}\right)$ from the 21 farms participating in the study.

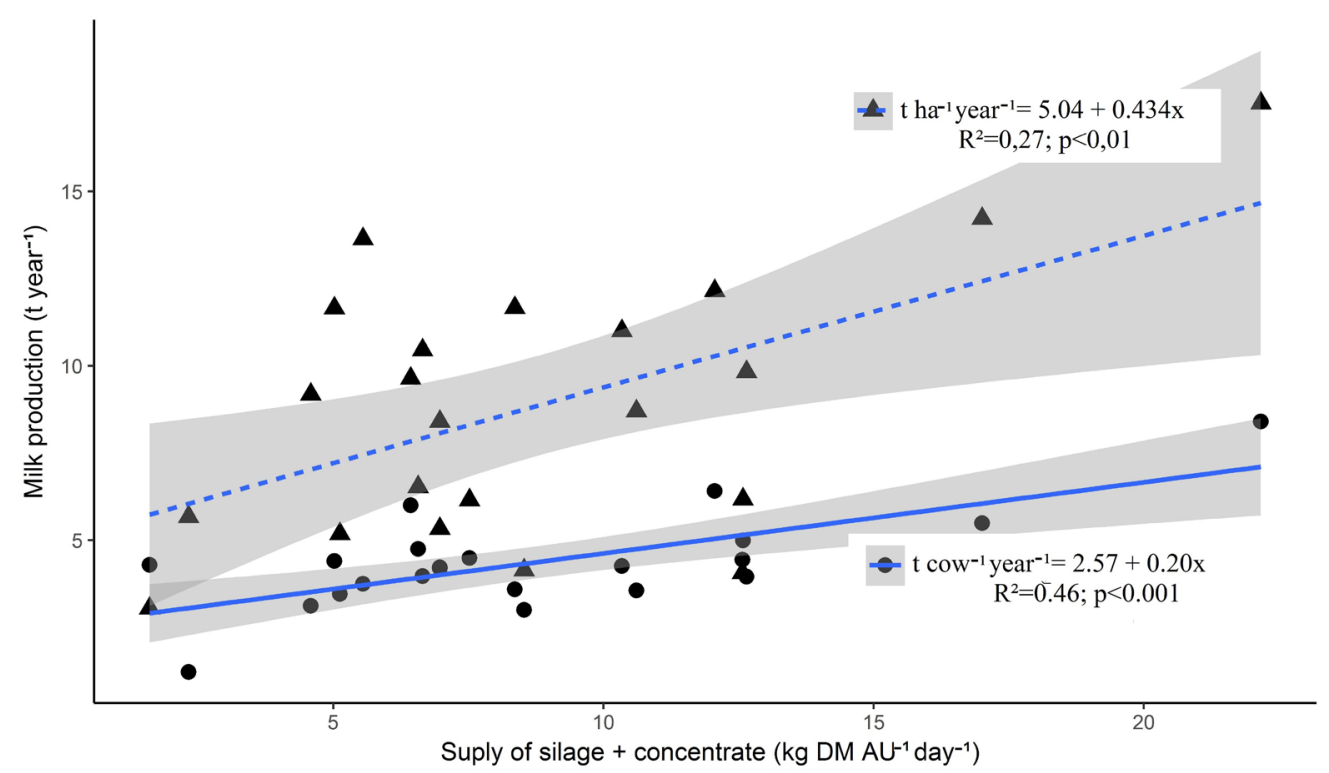


In this study it was noted that the amount of silage and concentrate used by the farmers are not based on the nutritional needs of cows, since the offered quantity is quite even within each farm during the whole year, regardless of cow's milk yield, lactation stage or pasture quality, and with no technical guidance. In only one of the farms cows' nutrition is oriented by a qualified professional. Nevertheless, in this farm the quantity of silage consumed by cows was unknown, not collectively nor even individually. When the interviewees were questioned about the reasons why they used this quantity of silage, answers were quite varied and controversial; the farmer "JT" said that he made a lot of silage because if he had pastures in areas very far from the milking room, cows would spend a lot of energy walking, and the farmer " $\mathrm{HG}$ " stated that it is a pity to produce pasture in plain areas close to home, because with silage he can get much more volume. Similarly, the answers to justify the quantity of silage they are using are discrepant: The farmers "RW" and "GR" state that the use of silage gives more stability to the rumen function and the milk production, whereas farmer " $\mathrm{CG}$ " says that he uses silage to meet energy needs in the cows' diet and, thus, guaranteeing good milk production.

These different responses show a heterogeneous knowledge about the use of silage, suggesting the need for greater dialogue among research, extension and farmers, for a more rational use of this resource. Silage has become, perhaps, the most important feed for dairy cattle in Western Santa Catarina, but this fact did not come with technical standards. This lack of criteria may cause an increase in production costs, a decrease in the production response in relation to the silage consumed by animals and a reduction in the sustainability of the activity.

Silage production is present in almost all dairy farms, and most of them produce it twice a year once in the season crop and once in the off-season crop. In all farms studied the silage is made out of maize, and occupy more than $50 \%$ of the area designated to dairy activity. The silage produced in the assessed farms is used internally. Data about silage area (season and off-season crop), about the percentage of the silage area in relation to pasture area, as well as about the silage yield are in Table 2.

Table 2. Planting area, silage production and \% of silage area, in 21 farms from Western Santa Catarina, in the 2014/15 harvest.

\begin{tabular}{|c|c|c|c|c|}
\hline Variable & $\mathrm{n}^{*}$ & Average & $\mathrm{SE}^{* *}$ & $\mathrm{CV} \% * * *$ \\
\hline Total silage area (season + off-season crop) (ha) & 21 & 8.46 & 1.18 & 65.4 \\
\hline Silage production in the season crop $\left(\mathrm{Mg} \mathrm{DM} \mathrm{ha}{ }^{-1}\right)$ & 21 & 8.77 & 0.49 & 26.3 \\
\hline Silage production in the off-season crop $\left(\mathrm{Mg} \mathrm{DM} \mathrm{ha}{ }^{-1}\right)$ & 18 & 7.64 & 0.46 & 28.3 \\
\hline Silage production (average $\mathrm{Mg} \mathrm{DM} \mathrm{ha}^{-1}$ ) & 21 & 8.21 & 0.43 & 24.8 \\
\hline$\%$ silage area/total area destined to milk & 21 & 59 & 4.83 & 38.3 \\
\hline
\end{tabular}

$* \mathrm{n}=$ number of farms; $* * \mathrm{SE}=$ Standard error; $* * * \mathrm{CV} \%=$ Coefficient of Variation.

To our knowledge there are no studies evaluating the volume of silage per area; therefore the comparison will be with studies evaluating the silage yield performed in the Southern region of Brazil. During the ensiling process, which begins with cutting plants to the closure of the silo, there may be significant losses due to fermentation, which may vary from $3 \%$ to $10 \%$ (JOHNSON et al., 2002; KLEINSCHMIT; KUNG JÚNIOR, 2006; OLIVEIRA et al., 2010), and physical losses, which may vary from 20 to 34\% (MCDONALD, 1991). Carvalho (2013) observed that most silos presented 
severe losses by effluents and a deteriorated layer on their upper part. In several experiments conducted in the state of Paraná, during the 2000/01, 2002/03 and 2006/07 harvests, it was possible to obtain productivities between 12.8 and $17.5 \mathrm{t} \mathrm{ha}^{-1}$ (LUPATINI et al., 2004), 14.4 to $22.9 \mathrm{t}$ ha $^{-1}$ (NEUMANN et al., 2005) and 12.0 to $12.5 \mathrm{t}$ ha $^{-1}$ (CASTOLDI et al., 2011). In a study conducted in Southwestern Paraná, whose climate is similar to the one in Western Santa Catarina, Paula et al., (2016) found an average productivity of $12.3 \mathrm{t} \mathrm{DM}$ ha $^{-1}$ of maize in the 2011/12 harvest. In another trial in the North of Paraná a production of 9,6 t $\mathrm{DM}^{-1} \mathrm{a}^{-1}$ was reported (MORAES et al., 2013). The average silage yield in a study conducted in 7 places in Southern Brazil, ranged from 11.3 to $14.8 \mathrm{t} \mathrm{ha}^{-1}$ (MITTELMANN et al., 2005). Considering a 30\% loss in the ensiling process, the data obtained in our study are similar to the ones reported in the recent literature.

Only two farms did not use transgenic seeds for the production of silage (Table 3). This fact was already mentioned by Honorato et al. (2014) and Kuhnen et al. (2015) as one of the challenges to enable the organic production, since it is not allowed for organic producers to feed animals with transgenic feed. Therefore, the farmers are required to produce all non-transgenic feedstuff in farm and take care of the cross-contamination from others in its own crops.

Table 3. Number (n) of farms, out of 21 making silage, that adopt the practices listed below.

\begin{tabular}{lc}
\hline Planting & $\mathrm{n}$ \\
\hline No-tillage with straw & 8 \\
No-tillage after grazing & 11 \\
Conventional & 2 \\
\hline Crop rotation & 2 \\
\hline Maize-soybean & 11 \\
Annual maize-pasture & 8 \\
Biannual maize-maize-pasture & \\
\hline Inputs & 20 \\
\hline Uses pesticides on maize culture & 19 \\
\hline Uses transgenic maize seeds & \\
\hline
\end{tabular}

As for the planting system used in the farms, it was possible to observe the use of a system identified as "no-tillage with straw covering", but that differs in most farms due to the lack of soil covering (Table 3). No-tillage is a cultivation system without soil plowing, with the presence of covering with residues from cultures and that may promote positive changes in fertility (FREIRE et al., 2001). The intensive use of land, according to the opinion of the interviewees, is not allowing the maintenance of the proper soil covering at the time of planting. In $60 \%$ of the farms (Table 3), planting is performed after the grazing of pastures by the animals or in conventional system, therefore, without soil cover. The constant removal of the produced biomass also affects negatively the quality of soil, reducing soil organic carbon (SOC), depending on the soil type (BLANCO-CANQUI; LAL, 2007, 2008; BLANCO-CANQUI et al., 2006; LAIRD; CHANG, 2013). Ploughing perennial pasture into silage of maize generate a non-recurrent 
emissions of $913 \mathrm{~kg}$ de $\mathrm{CO}_{2}$ eq $\mathrm{t}^{-1}$ fat-and-proteincorrected-milk, and contributes for global warming (VAN MIDDELAAR et al., 2013).

As for crop rotation, it was possible to observe that it is a practice not commonly used in the farms researched. Crop rotation was only used in two farms (Table 3), whereas in 11 farms, the interviewees answered that they practice crop rotation, but they do it without alternating plant family (i.e. the rotate maize with grass, all species of the same family (Poaceae)). In most cases, silage is always made on the same area and, in many cases, with two maize harvests (season and off-season crop), followed by pastures. The absence of crop rotation practices may lead to degradation, through aggregation and erosion, and to loss of fertility, as shown by an 11year experiment about the effects of crop rotation lack which led to a significant production decrease, whereas with the rotation, production remained stable (LOMBARDI-NETO et al., 2002). Most farmers say that they do not practice crop rotation because they do not have a proper area for that, which shows a certain awareness of the need to adopt this practice.

The use of pesticides in the cultivation of silage maize is also a rule in the current systems of the region; just one of the farms did not use pesticides and in $65 \%$ of the farms more than one pesticide is used (Table 4). Brazil is a world leader in pesticide consumption, and in spite of the existence of maximum residue limits for herbicides, insecticides and fungicides on pastures used in the nutrition of animals, there is little evaluation of the existence of this kind of residues in the milk consumed by the population. As a possible consequence, the presence of organophosphates in milk is frequent (BASTOS et al., 2011), and pesticide residues were found even in organic milk (GRANELLA et al., 2013).

Table 4. Silage production ( $\mathrm{t} \mathrm{DM} \mathrm{ha-1)} \mathrm{and} \mathrm{pesticide} \mathrm{use} \mathrm{in} \mathrm{the} \mathrm{cultivation} \mathrm{of} \mathrm{maize} \mathrm{in} \mathrm{the} \mathrm{2014/15} \mathrm{season} \mathrm{crop} \mathrm{and}$ off-season crop in 21 farms studied from Western Santa Catarina.

\begin{tabular}{lcccccc}
\hline \multirow{2}{*}{ Pesticide use } & \multicolumn{3}{c}{ Season crop } & \multicolumn{3}{c}{ Off-season crop } \\
\cline { 2 - 7 } & $\mathrm{n}$ & $\mathrm{tha}^{-1}$ & $\mathrm{SE}$ & $\mathrm{n}$ & t ha $^{-1}$ & $\mathrm{SE}$ \\
\hline No use & 1 & 6.7 & - & 1 & 6.2 & - \\
Pre- and/or post-emergent herbicide (H) & 6 & 8.0 & 1,00 & 4 & 6.8 & 0,73 \\
H + Fungicide (F) & 8 & 9.2 & 0,83 & 7 & 7.9 & 0,94 \\
H + F + Insecticide & 6 & 9.3 & 0,94 & 6 & 8.1 & 0,97 \\
\hline
\end{tabular}

$\mathrm{n}=$ number of farms; $\mathrm{SE}=$ Standard error.

Despite the dangerous consequences on the farmers' family and on consumers, the use of pesticides did not have an impact in the production, as can be seen in Table 4. The use of pesticides often has the justification of a great concern in maintaining the culture "clean", that is, free from other plants, diseases or pests, but it does not necessarily affects productivity, depending on other performed managements. The presence of spontaneous plants or pastures, or pests and diseases attacks, during the development of the maize culture, may not affect significantly its production.

The quantity of $\mathrm{N}$ used for the culture, through chemical or organic fertilization, varied between 63 and $373 \mathrm{~kg} \mathrm{ha}^{-1}$. The average was estimated in 201 $\mathrm{kg}$ of $\mathrm{N} \mathrm{ha}^{-1}$ in the season crop and $154 \mathrm{~kg}$ of $\mathrm{N} \mathrm{ha}^{-1}$ in the off-season crop. The $\mathrm{N}$ quantity recommended for the production of maize for silage follows the same recommendation of grain production, and varies from 30 to $80 \mathrm{~kg} \mathrm{~N} \mathrm{ha}^{-1}$, according to the availability of organic matter $(\mathrm{OM})$ and the previous cultivation, for a production up to $12 \mathrm{tha}^{-1}$. On top 
of that, it is recommended to add $20 \mathrm{~kg} \mathrm{ha}^{-1}$ of $\mathrm{N}$ for each biomass $t$ (CQFS-RS/SC, 2004). Since the availability of $\mathrm{OM}$ is directly correlated to the level of SOC in the soil (PRIBYL, 2010), its reduction implies the need to increase nitrogen fertilization, implying in this way a higher emission of $\mathrm{N}_{2} \mathrm{O}$ and $\mathrm{CO}_{2}$.

In this study, no correlation between the applied quantity of $\mathrm{N}$ and the silage production was found, nor between the applied volume of $\mathrm{P}$ and $\mathrm{K}$ and the silage produced. Our results are not in line with what is usually reported in the literature: a significant correlation between nitrogen doses and silage production (DAMIAN et al., 2017; NEUMANN et al., 2005; ZAVATTARO et al., 2012). This apparent discrepancy, is probably explained by the fact that most farmers used high amounts of fertilizers but not based on technical criteria and guidance.

The lack of criteria for the correct use of fertilizer can result in an unnecessary increase in greenhouse gas (GHG) emissions, contributing to climate change, as well as impacting on water contamination. The non use of technical criteria to fertilize maize crops destined to silage can be seen in this study (Table 5), since only 5 establishments used soil analysis to plan fertilization. Interesting, the use of fertilizers based on soil analysis resulted in higher silage production, when compared to fertilization without soil analysis, especially in the season crop. The importance of an accurate fertilization can be noticed in a study by Giuliano et al. (2016), where they showed that a reduction in the use of nitrogen fertilizer and herbicides did not affect production, but decreased GHG emission and energy expenditure. Soil analysis is one of the main means to determine the need to apply fertilizers on annual cultures (CQFS-RS/SC, 2004). The effects of an inappropriate and excessive use of fertilizers go beyond production costs and, in addition, they impact on the increase of greenhouse gas emissions (DE BOER et al., 2011) and other environmental externalities.

Table 5. Silage production ( $\mathrm{t} \mathrm{DM} \mathrm{ha}{ }^{-1}$ ) of the 21 farms studied from Western Santa Catarina, according with the use or not of soil analysis for the fertilization recommendation on maize crop in both seasons.

\begin{tabular}{lcccccc}
\hline \multirow{2}{*}{ Referring to soil analysis } & \multicolumn{3}{c}{ Season crop } & \multicolumn{3}{c}{ Off-season crop } \\
\cline { 2 - 7 } & $\mathrm{n}$ & $\mathrm{t} \mathrm{ha}^{-1}$ & $\mathrm{SE}$ & $\mathrm{n}$ & $\mathrm{t} \mathrm{ha}^{-1}$ & $\mathrm{SE}$ \\
\hline Follow recommendation & 5 & $10.9 \mathrm{a}^{*}$ & 0.93 & 4 & $9.1 \mathrm{a}$ & 1.16 \\
Only soil correction use & 6 & $7.8 \mathrm{~b}$ & 0.39 & 5 & $7.3 \mathrm{a}$ & 0.69 \\
$\begin{array}{l}\text { Do not follow the recommendation or do } \\
\text { not perform soil analysis }\end{array}$ & 10 & $8.0 \mathrm{~b}$ & 0.71 & 8 & $7.0 \mathrm{a}$ & 0.71 \\
\hline
\end{tabular}

*Numbers followed by the same letter do not differ among themselves by Tukey $\mathrm{p}<0.05 ; \mathrm{n}=$ number of farms.

\section{Conclusions}

Milk production in Western Santa Catarina is very dependent on maize silage, even in pasture production systems. The farmers seem to rely heavily on maize silage as a mean to ensure annual availability of feed and to increase milk production, although they lack the use of technical criteria for the production and supply of silage to dairy cows.
As a result, there is an unnecessary increase in the cost of dairy production and potential contamination of the environment in the West of Santa Catarina. Overall the production systems and the quantity of silage produced and fed to the cows do not follow technical criteria; thus silage yield and its use could be improved if following strategies to better allocate crop inputs. 


\section{Acknowledgments}

Thanks to the 22 farmers who collaborated with interviews and on-site visits. To FAPESC for the scholarship to Adenor V. Wendling and to CNPq for the scholarship to Luiz C. P. Machado Filho. To the colleagues from the Laboratório de Etologia Aplicada e Bem-Estar Animal (LETA) for the support. We would like to acknowledge the financial support of the research from PGA-UFSC and from CNPq, through the MCTI/MPA/MDA/MEC/MPA/ CNPq, Chamada n. 81/2013.

\section{References}

AL-MARASHDEH, O.; GREGORINI, P.; EDWARDS, G. R. Effect of time of maize silage supplementation on herbage intake, milk production, and nitrogen excretion of grazing dairy cows. Journal of Dairy Science, Savoy, v. 99, n. 9, p. 7123-7132, 2016.

ALVARES, C. A.; STAPE, J. L.; SENTELHAS, P. C.; MORAES GONÇALVES, J. L. de; SPAROVEK, G. Köppen's climate classification map for Brazil. Meteorologische Zeitschrift, Stuttgart, v. 22, n. 6, p. 711$728,2013$.

BACENETTI, J.; FUSI, A. The environmental burdens of maize silage production: influence of different ensiling techniques. Animal Feed Science and Technology, Amsterdam, v. 204, n. 2015, p. 88-98, 2015.

BALCÃO, L. F.; LONGO, C.; COSTA, J. H. C.; ULLERGÓMEZ, C.; MACHADO FILHO, L. C. P.; HÖTZEL, M. J. Characterisation of smallholding dairy farms in southern Brazil. Animal Production Science, Clayton, v. 57, n. 4, p. 735-745, 2017.

BASSET-MENS, C.; LEDGARD, S.; BOYES, M. Ecoefficiency of intensification scenarios for milk production in New Zealand. Ecological Economics, Amsterdam, v. 68, n. 6, p. 1615-1625, 2009.

BASTOS, L. H. P.; CARDOSO, M. H. W. M.; NÓBREGA, A. W. da; JACOB, S. de C. Possíveis fontes de contaminação do alimento leite, por agrotóxicos, e estudos de monitoramento de seus resíduos: uma revisão nacional. Caderno de Saúde Coletiva, Rio de Janeiro, v. 19, n. 1, p. 51-60, 2011.

BENCHAAR, C.; HASSANAT, F.; GERVAIS, R.; MASSÉ, D. I.; PETIT, H. V. Methane production, nutrient digestion, ruminal fermentation, $\mathrm{N}$ balance, and milk production of cows fed timothy silage- or alfalfa silage-based diets. Journal of Dairy Science, Savoy, v. 97, n. 10, p. 6463-74, 2014.

BERNARDES, T. F.; RÊGO, A. C. do; CASAGRANDE, D. R.; LARA, M. A. S.; LIMA, L. M.; SILVA, N. C. da. Produção e uso de silagens em fazendas leiteiras em três mesorregiões do Estado de Minas Gerais. Revista de Ciências Agrárias, Londrina, v. 56, n. 2, p. 133-138, 2013.

BLANCO-CANQUI, H.; LAL, R. Corn stover removal impacts on micro-scale soil physical properties. Geoderma, Amsterdam, v. 145, n. 3-4, p. 335-346, 2008.

Soil and crop response to harvesting corn residues for biofuel production. Geoderma, Amsterdam, v. 141, n. 3-4, p. 355-362, 2007.

BLANCO-CANQUI, H.; LAL, R.; POST, W. M.; IZAURRALDE, R. C.; OWENS, L. B. Rapid changes in soil carbon and structural properties due to stover removal from no-till corn plots. Soil Science, Philadelphia, v. 171, n. 6 , p. $468-482,2006$.

CARVALHO, I. Q. de. Tecnologia da produção de silagem de milho em sistemas de produção de leite. 2013. Tese (Doutorado) - Centro de Ciências Agrárias, Programa de Pós-Graduação em Zootecnia. Universidade Estadual de Maringá, Maringá.

CASTOLDI, G.; COSTA, M. S. S. de. M.; COSTA, L. A. de. M.; PIVETTA, L. A.; STEINER, F. Sistemas de cultivo e uso de diferentes adubos na produção de silagem e grãos de milho. Acta Scientiarum. Agronomy, Maringá, v. 33, n. 1, p. 139-146, 2011.

COMISSÃO DE QUÍMICA E FERTILIDADE DO SOLO - CQFS-RS/SC. Manual de adubação e calagem para os estados do Rio Grande do Sul e Santa Catarina. 10. ed. Porto Alegre: Sociedade Brasileira de Ciência do Solo/ Núcleo Regional Sul, 2004.

COSTA, J. H. C.; HÖTZEL, M. J.; LONGO, C.; BALCÃO, L. F. A survey of management practices that influence production and welfare of dairy cattle on family farms in southern Brazil. Journal of Dairy Science, Savoy, v. 96, n. 1, p. 307-317, 2013.

DAMIAN, J. M.; ROZ, C. O. da; SILVA, R. F. da; COLDEBELLA, I. J.; SIMON, D. H. N , P or K doses on the dry matter and crude protein yield in maize and sorghum for silage 1. Pesquisa Agropecuária Tropical, Goiânia, v. 47, n. 1, p. 53-61, 2017.

DE BOER, I. J. M.; CEDERBERG, C.; EADY, S.; GOLLNOW, S.; KRISTENSEN, T.; MACLEOD, M.; MEUL, M.; NEMECEK, T.; PHONG, L. T.; THOMA, G.; VAN DER WERF, H. M. G.; WILLIAMS, A. G.; ZONDERLAND-THOMASSEN, M. A. Greenhouse gas 
mitigation in animal production: towards an integrated life cycle sustainability assessment. Current Opinion in Environmental Sustainability, Amsterdam, v. 3, n. 5, p. 423-431, 2011.

FERRIS, C. P.; BINNIE, R. C.; FROST, J. P.; PATTERSON, D. C. Effect of offering silage during housing at night on the performance of grazing dairy cows and on labour requirements. Grass and Forage Science, Indianápolis, v. 63, n. 1, p. 138-151, 2008.

FREIRE, F. M.; VASCONCELLOS, C. A.; FRANÇA, G. E. de. Manejo da fertilidade do solo em sistema plantio direto. Informe Agropecuário, Belo Horizonte, v. 22, n. 208, p. 49-62, 2001.

GIULIANO, S.; RYAN, M. R.;VÉRICEL, G.; RAMETTI, G.; PERDRIEUX, F.; JUSTES, E.; ALLETTO, L. Lowinput cropping systems to reduce input dependency and environmental impacts in maize production: A multicriteria assessment. European Journal of Agronomy, Amsterdam, v. 76, p. 160-175, 2016.

GOMES, M. de S.; VON PINHO, R. G.; RAMALHO, M. A. P.; FERREIRA, D. V.; BRITO, A. H. de. Variabilidade genética em linhagens de milho nas características relacionadas com a produtividade de silagem. Pesquisa Agropecuária Brasileira, Brasília, v. 39, n. 9, p. 879-885, 2004.

GRANELLA, V.; VENTORINI, C. G.; PIGATTO, G. M.; NÖRNBERG, J. L.; COSTABEBER, I. H. Resíduos de agrotóxicos em leites pasteurizados orgânicos e convencionais. Semina: Ciências Agrárias, Londrina, v. 34, n. 4, p. 1731-1739, 2013.

GREGORINI, P.; GUNTER, S. A.; BECK, P. A.; SODER, K. J.; TAMMINGA, S. Review: the interaction of diurnal pattern, ruminal metabolism, nutrient supply, and management in cattle. The Professional Animal Scientist, Champaing, v. 24, n. 4, p. 308-318, 2008.

GUYADER, J.; LITTLE, S.; KRÖBEL, R.; BENCHAAR, C.; BEAUCHEMIN, K. A. Comparison of greenhouse gas emissions from corn- and barley-based dairy production systems in Eastern Canada. Agricultural Systems, Amsterdam, v. 152, p. 38-46, 2017.

HONORATO, L. A.; SILVEIRA, I. D. B.; MACHADO FILHO, L. C. P. Produção de leite orgânico e convencional no Oeste de Santa Catarina : caracterização e percepção dos produtores. Revista Brasileira de Agroecologia, Cruz Alta, v. 9, n. 2, p. 60-69, 2014.

INSTITUTO BRASILEIRO DE GEOGRAFIA E ESTATÍSTICA - IBGE. Diretoria de Pesquisas. Coordenação de Agropecuária, Produção da Pecuária Municipal. Rio de Janeiro: IBGE, 2015. Disponível em: <biblioteca.ibge.gov.br/visualizacao/periodicos/84/ ppm_2015_v43_br.pdf>. Acesso em: 26 abr. 2017.

JOHNSON, L. M.; HARRISON, J. H.; DAVIDSON, D.; MAHANNA, W. C.; SHINNERS, K.; LINDER, D. Corn silage management: effects of maturity, inoculation, and mechanical processing on pack density and aerobic stability. Journal of Dairy Science, Savoy, v. 85, n. 2, p. 434-444, 2002.

KAISER, A. G.; MORAN, J. B.; PILTZ, J. W. Feeding silage to dairy cows. In: KAISER, A. G.; PILTZ, J. W.; BURNS, H. M.; GRIFFITHS, N. W. Successfull silage. Orange: Dairy Australia \& NSW Department of Primary Industries, 2004. p. 336-357.

KLEINSCHMIT, D. H.; KUNG JÚNIOR, L. A metaanalysis of the effects of Lactobacillus buchneri on the fermentation and aerobic stability of corn and grass and small-grain silages. Journal of Dairy Science, Savoy, v. 89, n. 10, p. 4005-4013, 2006.

KUHNEN, S.; STIBUSKI, R. B.; HONORATO, L. A.; MACHADO FILHO, L. C. P. Farm management in organic and conventional dairy production systems based on pasture in Southern Brazil and its consequences on production and milk quality. Animals, Basel, v. 5, n. 3, p. 479-494, 2015.

LAIRD, D. A.; CHANG, C. W. Long-term impacts of residue harvesting on soil quality. Soil and Tillage Research, Netherlands, v. 134, p. 33-40, 2013.

LOMBARDI-NETO, F.; DECHEN, S. C. F.; CONAGIN, A.; BERTONI, J. Rotação de culturas: análise estatística de um experimento de longa duração em campinas (SP). Bragantia, Campinas, v. 61, n. 2, p. 127-141, 2002.

LUPATINI, G. C.; MACCARI, M.; ZANETTE, S.; PIACENTINI, E.; NEUMANN, M. Avaliação do desempenho agronômico de híbridos de milho (Zea mays, L.) para produção de silagem. Revista Brasileira de Milho e Sorgo, Sete Lagoas, v. 3, n. 2, p. 193-203, 2004.

MACHADO FILHO, L. C. P.; D’ÁVILA, L. M.; SILVA KAZAMA, D. C. da; BENTO, L. L.; KUHNEN, S. Productive and economic responses in grazing dairy cows to grain supplementation on family farms in the South of Brazil. Animals, Basel, v. 4, n. 3, p. 463-475, 2014.

MCDONALD, P. The biochemistry of silage. 2. ed. Chalcombe: John Wiley \& Sons, Ltd., 1991. 340 p.

MITTELMANN, A.; SOUZA SOBRINHO, F. de; SILVA E OLIVEIRA, J.; FERNANDES, S. B. V.; LAJÚS, C. A.; MIRANDA, M.; ZANATTA, J. C.; MOLETTA, J. L. Avaliação de híbridos comerciais de milho para utilização como silagem na Região Sul do Brasil. Ciência Rural, Santa Maria, v. 35, n. 3, p. 684-690, 2005. 
MORAES, S. D. de; JOBIM, C. C.; SILVA, M. S. da; MARQUARDT, F. I. Production and chemical composition of hybrid sorghum and corn for silage. Revista Brasileira de Saúde e Produção Animal, v. 14, n. 4, p. 624-634, 2013.

NATIONAL RESEARCH COUNCIL - NRC. Nutrients requirements of dairy cattle. $7^{\text {th }}$ ed. Washington: The National Academies Press, 2001.

NEUMANN, M.; SANDINI, I. E.; LUSTOSA, S. B. C.; OST, P. R.; ROMANO, M. A.; FALBO, M. K.; PANSERA, E. R. Yield and production components of corn (Zea mays L.) for silage as a result of nitrogen fertilization. Revista Brasileira de Milho e Sorgo, Sete Lagoas, v. 4, n. 3, p. 418-427, 2005.

OLIVEIRA, L. B. de; PIRES, A. J. V.; CARVALHO, G. G. P. de; RIBEIRO, L. S. O.; ALMEIDA, V. V. de; PEIXOTO, C. A. de M. Perdas e valor nutritivo de silagens de milho, sorgo-sudão, sorgo forrageiro e girassol. Revista Brasileira de Zootecnia, Viçosa, MG, v. 39, n. 1, p. 61-67, 2010.

PAULA, F. L. M. de; MENEZES, L. F. G. de; PARIS, W.; RONSANI, R.; HOPPEN, S. M.; CIESCA, J. Silage production and the chemical composition of corn and Grass- tanzania intercropping. Semina: Ciências Agrárias, Londrina, v. 37, n. 3, p. 1607-1616, 2016.

PENNO, J. W.; MACDONALD, K. A.; HOLMES, C. W.; DAVIS, S. R.; WILSON, G. F.; BROOKES, I. M.; THOM, E. R. Responses to supplementation by dairy cows given low pasture allowances in different seasons 1. Pasture intake and substitution. Animal Science, New York, v. 82, n. 5, p. 661-670, 2006.

PÉREZ-PRIETO, L. A.; PEYRAUD, J. L.; DELAGARDE, R. Substitution rate and milk yield response to corn silage supplementation of late-lactation dairy cows grazing low-mass pastures at 2 daily allowances in autumn. Journal of Dairy Science, Savoy, v. 94, n. 7, p. 3592-3604, 2011.

PRIBYL, D. W. A critical review of the conventional SOC to SOM conversion factor. Geoderma, Amsterdam, v. 156, n. 3-4, p. 75-83, 2010.
R CORE TEAM - R: a language and environment for statistical computing. Vienna: Editora, 2016. Available at: $<$ https://www.r-project.org/>. Accessed at: 19 may 2017.

SANTACATARINA. Síntese anual da agricultura de Santa Catarina 2015- 2016. Florianópolis: EPAGRI/CEPA, 2017. 191 p. Disponível em: <http://docweb.epagri. sc.gov.br/website_cepa/publicacoes/Sintese_2016.pdf>. Accessed at: 27 Apr. 2017.

SCHERER, E. E.; AITA, C.; BALDISSERA, I. T. Avaliação da qualidade do esterco líquido de suíno da região Oeste Catarinense para fins de utilização como fertilizante. Florianópolis: Epagri, 1996. 46 p.

SHAPIRO, S. S.; WILK, M. B. An analysis of variance test for normality (complete samples). Biometrika, Oxford, v. 52, n. 3-4, p. 591-611, 1965.

SILVA, M. S. J. da; JOBIM, C. C.; POPPI, E. C.; TRES, T. T.; OSMARI, M. P. Production technology and quality of corn silage for feeding dairy cattle in Southern Brazil. Revista Brasileira de Zootecnia, Viçosa, MG, v. 44, n. 9, p. 303-313, 2015.

TAWEEL, H. Z.; TAS, B. M.; DIJKSTRA, J.; TAMMINGA, S. Intake regulation and grazing behavior of dairy cows under continuous stocking. Journal of Dairy Science, Savoy, v. 87, n. 10, p. 3417-27, 2004.

VAN MIDDELAAR, C. E.; BERENTSEN, P. B. M.; DIJKSTRA, J.; DE BOER, I. J. M. Evaluation of a feeding strategy to reduce greenhouse gas emissions from dairy farming: the level of analysis matters. Agricultural Systems, Amsterdam, v. 121, p. 9-22, 2013.

WENDLING, A. V.; RIBAS, C. C. E. Indice de conformidade do pastoreio racional Voisin (IC-PRV). Revista Brasileira de Agroecologia, Cruz Alta, v. 8, n. 3, p. 26-38, 2013.

WICKHAM, H. ggplot2: elegant graphics for data analysis. New York: Springer, 2016. 260 p.

ZAVATTARO, L.; MONACO, S.; SACCO, D.; GRIGNANI, C. Options to reduce $\mathrm{N}$ loss from maize in intensive cropping systems in Northern Italy. Agriculture, Ecosystems \& Environment, Amsterdam, v. 147, n. 15, p. 24-35, 2012. 
